\title{
HUBUNGAN ANTARA SUPLEMENTASI VITAMIN A PADA IBU NIFAS DAN MORBIDITAS BAYI UMUR 0-6 BULAN DI KECAMATAN CIAMPEA, KABUPATEN BOGOR
}

\author{
(The Correlation between Vitamin A Supplementation among Postpartum Mothers and the Morbidity of \\ Infants 0-6 Months in Ciampea Sub-district, Bogor)
}

Mei Rini Safitri ${ }^{*}$ dan Dodik Briawan ${ }^{1}$

'Departemen Gizi Masyarakat, Fakultas Ekologi Manusia (FEMA), Institut Pertanian Bogor, Bogor 16680

\begin{abstract}
The objective of this research was to analyze correlation between vitamin A supplementation among postpartum mothers and the morbidity of infant 0-6 month in Ciampea Sub-district. A cross sectional study of 56 subjects was conducted. The data collected in this study were breastfeeding practices, vitamin $A$ supplementation, immunization and morbidity. The results showed that infants $0-6$ months suffered from acute respiratory infection (ARI) 66.1\%, fever (25.0\%), diarrhea (14.3\%), skin disease (7.1\%), hepatitis B (3.6\%), dengue fever (1.8\%), and sprue (1.8\%). There were a correlation between immunization and frequency/ duration of hepatitis $B$; between the number of taking vitamin $A$ supplement and incident of diseases as well as complementary feeding; complete immunization and duration of all illness $(p<0.05)$. The logistic regression analysis showed that there were significant effects of complete immunization with duration of all illness (OR=0.110; 95\% Cl:0.013-0.940), and between number of taking vitamin A supplement with incident of diseases (OR=0.103; 95\% Cl:0.015-0.715).
\end{abstract}

Keywords: infant, morbidity, postpartum maternal, vitamin A

\begin{abstract}
ABSTRAK
Penelitian ini bertujuan menganalisis hubungan antara suplementasi vitamin A pada ibu nifas dan morbiditas bayi umur 0-6 bulan di Kecamatan Ciampea. Desain yang digunakan adalah cross sectional dengan subjek sebanyak 56 bayi. Data yang digunakan meliputi riwayat pemberian ASI, suplementasi vitamin A, imunisasi dan morbiditas. Hasil penelitian menunjukkan bahwa bayi 0-6 bulan pernah menderita Infeksi Saluran Pernapasan Akut (ISPA) $(66.1 \%)$, demam (25.0\%), diare (14.3\%), penyakit kulit $(7.1 \%)$, hepatitis B $(3.6 \%)$, demam berdarah $(1.8 \%)$, dan sariawan (1.8\%). Hasil penelitian juga menunjukkan bahwa terdapat hubungan antara pemberian imunisasi dengan frekuensi dan lama penyakit hepatitis B, jumlah konsumsi vitamin A dengan kejadian sakit, pemberian makanan atau minuman tambahan selain ASI dan kelengkapan imunisasi dengan lama sakit semua jenis penyakit $(p<0.05)$. Hasil uji regresi logistik menunjukkan bahwa terdapat pengaruh yang signifikan antara kelengkapan imunisasi dengan lama sakit semua jenis penyakit $(\mathrm{OR}=0.110 ; 95 \% \mathrm{Cl}: 0.013-0.940)$, jumlah konsumsi vitamin A dengan kejadian sakit (OR=0.103; 95\% Cl:0.015-0.715).
\end{abstract}

Kata kunci: bayi, ibu nifas, morbiditas, vitamin A

"Korespondensi: Departemen Gizi Masyarakat, Fakultas Ekologi Manusia (FEMA), Institut Pertanian Bogor, Bogor 16680. Email: mei.rinisafitri09@gmail.com 


\section{PENDAHULUAN}

Kesehatan merupakan investasi untuk keberhasilan pembangunan bangsa dan menjadi hak asasi manusia. Derajat kesehatan suatu bangsa tercapai apabila status gizi masyarakat sudah baik dan masalah gizi terselesaikan. Masalah gizi memiliki dimensi yang luas sehingga menjadi masalah yang kompleks karena penyebabnya multi faktor dan multi dimensi. Masalah gizi tersebut dapat mengakibatkan peningkatan angka kejadian morbiditas dan mortalitas.

Salah satu zat gizi yang berperan dalam menurunkan morbiditas dan mortalitas adalah vitamin A. Kekurangan vitamin A dapat menurunkan fungsi kekebalan tubuh sehingga dapat meningkatkan terjadinya morbiditas dan mortalitas dari beberapa penyakit infeksi seperti diare, infeksi saluran pernapasan bawah, dan campak. Peranan vitamin A adalah membentuk respon imun melalui peningkatan respon imun sel $T$ dan retinol yang berpengaruh terhadap pertumbuhan dan diferensiasi limfosit $B$ (leukosit yang berperan dalam proses kekebalan humoral) (Almatsier 2004).

Saat ini defisiensi vitamin A masih dihadapi oleh negara-negara berkembang termasuk Indonesia. Salah satu cara yang dapat dilakukan untuk mengatasi masalah tersebut yaitu melalui program suplementasi vitamin A pada ibu nifas. Program tersebut pertama kali dipublikasikan pada tahun 1997 oleh WHO, UNICEF, dan IVACG yang merekomendasikan pemberian suplemen vitamin A dosis tunggal 200000 IU pada ibu nifas segera setelah melahirkan. Kemudian terdapat perubahan yang merekomendasikan dosis pemberian suplemen vitamin A menjadi 400 000 IU pada tahun 2001 saat pertemuan IVACG XX di Vietnam (Rice 2007). Beberapa studi menunjukkan efek dari suplementasi vitamin A pada ibu nifas. Menurut Ross dan Harvey (2003), suplementasi vitamin A dosis tinggi pada ibu nifas merupakan strategi yang efektif dalam memperbaiki status vitamin A pada bayi melalui pemberian ASI. Selain itu, Basu et al. (2003) menyatakan bahwa suplementasi vitamin A dosis tinggi pada ibu nifas di India dapat menurunkan morbiditas pada bayi.

Sejak tahun 2011, suplementasi vitamin A pada ibu nifas tidak direkomendasikan oleh WHO sebagai program kesehatan masyarakat untuk mengatasi morbiditas dan mortalitas pada ibu dan anak karena bukti yang menunjukkan efek dari suplemen vitamin A terhadap morbiditas dan mortalitas masih rendah. Ibu nifas seharusnya memenuhi kebutuhan gizinya dengan mengonsumsi makanan yang sehat. Asupan vitamin A yang direkomendasikan bagi ibu nifas sebesar $850 \mathrm{RE} / \mathrm{hari}$, namun untuk beberapa area mungkin masih sulit untuk mencapainya melalui konsumsi makanan (WHO 2011). Menurut Martins et al. (2010), suplementasi vitamin A pada ibu nifas berpengaruh positif terhadap status vitamin A ibu, namun tidak berpengaruh pada status vitamin A bayi dua bulan setelah pemberian dosis tunggal. Menurut Gogia dan Sachdev (2010), suplementasi vitamin A pada ibu nifas tidak berpengaruh terhadap morbiditas dan mortalitas. Selain itu, suplementasi vitamin A memiliki manfaat yang terbatas pada morbiditas dan mortalitas ibu dan bayi (Menegozzo et al. 2010).

Berdasarkan uraian di atas terdapat pro kontra mengenai suplementasi vitamin A pada ibu nifas. Penelitian ini bertujuan untuk menganalisis hubungan suplementasi vitamin A pada ibu nifas dan morbiditas pada bayi umur 0-6 bulan di Kecamatan Ciampea, Kabupaten Bogor.

\section{METODE}

\section{Desain, Tempat, dan Waktu}

Desain yang digunakan dalam penelitian ini adalah cross sectional. Penelitian dilakukan pada bulan Mei-Juni 2013. Proses pengumpulan data dilakukan di Kecamatan Ciampea, Kabupaten Bogor.

\section{Jumlah dan Cara Penarikan Subjek}

Subjek pada penelitian ini bayi berumur 0-6 bulan (periode kelahiran Desember 2012-Juni 2013). Penentuan subjek dilakukan secara purposive. Penentuan subjek menggunakan kriteria inklusi sebagai berikut: 1) subjek berumur 0-6 bulan, 2) ibu subjek mengonsumsi suplemen vitamin A sebanyak 1 atau 2 kapsul (200 000 IU) setelah melahirkan, 3) subjek pernah diberi ASI, 4) subjek lahir normal, 5) usia kelahiran subjek cukup bulan, 6) subjek tidak BBLR, dan 7) ibu subjek bersedia diwawancarai. Jumlah subjek dalam penelitian ini sebanyak 56 terdiri atas 20 subjek dari Puskesmas Induk Ciampea, 18 subjek dari Puskesmas Ciampea Udik, 10 subjek dari Puskesmas Cihideung Udik dan 8 subjek dari Puskesmas Pasir.

\section{Jenis dan Cara Pengumpulan Data}

Data primer dikumpulkan melalui wawancara dengan menggunakan instrumen kuesioner meliputi riwayat pemberian ASI, konsumsi suplemen vitamin A, riwayat imunisasi, dan riwayat morbiditas.

\section{Pengolahan dan Analisis Data}

Morbiditas ditentukan dari frekuensi, lama serta kejadian sakit dengan menanyakan apakah dari lahir sampai saat pengambilan data bayi pernah mengalami sakit seperti demam tinggi, batuk, pilek, diare, dan lain-lain dan ditanya frekuensi dan lama sakit dari masing-masing jenis penyakit. Untuk keperluan analisis, data morbiditas dilihat dari nilai median masing-masing jenis penyakit atau gabungan semua jenis penyakit (Untoro et al. 2005). Data tersebut kemudian dikelompokkan menjadi dua ka- 
tegori yaitu morbiditas rendah dan morbiditas tinggi. Rendah jika frekuensi dan lama sakit subjek $\leq$ median, tinggi jika frekuensi dan lama sakit subjek > median. Untuk melihat hubungan antara variabel digunakan uji Chi Square. Selain itu, dilakukan uji regresi logistik untuk mendapatkan nilai Odds Ratio (OR) variabel independen terhadap variabel dependen.

\section{HASIL DAN PEMBAHASAN}

\section{Morbiditas}

Sebagian besar subjek pernah sakit terhitung dari lahir sampai saat penelitian (82.1\%). Jenis penyakit yang diderita oleh subjek yaitu ISPA (66.1\%), demam $(25.0 \%)$, diare $(14.3 \%)$, penyakit kulit $(7.1 \%)$, hepatitis B (3.6\%), DBD (1.8\%), dan sariawan (1.8\%). Sebagian besar frekuensi sakit subjek termasuk dalam kategori morbiditas rendah baik dari masingmasing jenis penyakit maupun gabungan dari semua jenis penyakit. Sebaran subjek menurut kategori lama sakit disajikan pada Tabel 1.

Sebagian besar lama sakit subjek juga termasuk dalam kategori morbiditas rendah baik dari masing-masing jenis penyakit maupun gabungan dari semua jenis penyakit. Sebaran subjek menurut kategori frekuensi sakit disajikan pada Tabel 1.

\section{Suplementasi Vitamin A}

Banyak penelitian yang berhubungan dengan suplementasi vitamin A pada ibu nifas dan hasilnya terdapat beberapa penelitian yang menunjukkan efek positif atau sebaliknya dari suplementasi vitamin A tersebut. Hasil penelitian Basu et al. (2003) menyatakan bahwa suplementasi vitamin A dosis tinggi (209 $\mu \mathrm{mol}$ retinol) pada ibu nifas di India dapat menurunkan morbiditas pada bayi. Menurut Ross dan Harvey (2003) suplementasi vitamin A dosis tinggi pada ibu nifas merupakan strategi yang efektif dalam memperbaiki status vitamin A pada bayi melalui pemberian ASI. Namun demikian terdapat beberapa penelitian yang tidak menunjukkan efek positif dari suplementasi vitamin A. Hasil penelitian Newton et al. (2005) menunjukkan bahwa tidak ditemukan pengaruh suplementasi vitamin A pada ibu nifas dan bayi terhadap respon imun tubuh untuk vaksin tetanus dan polio.

Selain itu, Malaba et al. (2005) menyatakan bahwa suplementasi vitamin A pada ibu nifas atau bayi tidak dapat menurunkan mortalitas bayi pada wanita negatif HIV dengan status vitamin A yang cukup. Penelitian Ayah et al. (2007) juga menunjukkan bahwa suplementasi vitamin A pada ibu nifas tidak dapat meningkatkan serum retinol dan simpanan pada bayi. Berdasarkan hasil penelitian Ramakrishnan et al. (1995), perbedaan morbiditas penyakit diare dan pernapasan antara dua kelompok perlakuan secara statistik tidak signifikan dan hasil penelitian ini tetap tidak berubah setelah analisis multivariat pengaruh dari umur, jenis kelamin, status sosial ekonomi, sanitasi dan lain-lain. Penelitian ini juga sama dengan penelitian terbaru yang mengindikasikan bahwa suplementasi vitamin A tidak menurunkan morbiditas pada anak dengan defisiensi vitamin A ringan hingga sedang dimana akses pelayanan kesehatan dan imunisasi baik.

Persentase cakupan program suplementasi vitamin A pada ibu nifas di Kecamatan Ciampea pada tahun 2012 sebesar 85.8\%. Persentase tersebut sudah melebihi rata-rata cakupan suplementasi vitamin A Kabupaten Bogor yaitu sebesar 78.6\% (Dinkes 2012). Target yang ditetapkan oleh Rencana Strategis Depkes mengenai cakupan suplementasi vitamin A sebesar 80\% (Depkes 2009). Data tersebut menunjukkan bahwa cakupan suplementasi vitamin A pada ibu nifas di Kecamatan Ciampea sudah melebihi target yang ditetapkan. Menurut Depkes (2009), suplementasi vitamin A dosis tinggi (warna merah) dengan dosis 200000 IU harus diberikan kepada ibu nifas karena dapat mencegah infeksi pada ibu nifas, kesehatan ibu cepat pulih setelah melahirkan, pemberian 1 kapsul vitamin A merah cukup untuk meningkatkan kandungan vitamin A dalam ASI selama 60 hari dan pemberian 2 kapsul vitamin A merah

Tabel 1. Sebaran Subjek menurut Kategori Lama Sakit dan Frekuensi Sakit

\begin{tabular}{|c|c|c|c|c|c|c|c|c|c|c|}
\hline \multirow{3}{*}{ Jenis penyakit } & \multicolumn{5}{|c|}{ Kategori Lama Sakit } & \multicolumn{5}{|c|}{ Kategori Frekuensi Sakit } \\
\hline & \multirow{2}{*}{$\begin{array}{c}\text { Nilai } \\
\text { median }\end{array}$} & \multicolumn{2}{|c|}{$\begin{array}{l}\leq \text { median } \\
\text { (rendah) }\end{array}$} & \multicolumn{2}{|c|}{$\begin{array}{c}\text { > median } \\
\text { (tinggi) }\end{array}$} & \multirow{2}{*}{$\begin{array}{c}\text { Nilai } \\
\text { median }\end{array}$} & \multicolumn{2}{|c|}{$\begin{array}{l}\leq \text { median } \\
\text { (rendah) }\end{array}$} & \multicolumn{2}{|c|}{$\begin{array}{c}>\text { median } \\
\text { (tinggi) }\end{array}$} \\
\hline & & $\mathrm{n}$ & $\%$ & $\mathrm{n}$ & $\%$ & & $\mathrm{n}$ & $\%$ & $\mathrm{n}$ & $\%$ \\
\hline ISPA & 3 & 32 & 57.1 & 24 & 42.9 & 1 & 44 & 78.6 & 12 & 21.4 \\
\hline Diare & 0 & 48 & 85.7 & 8 & 14.3 & 0 & 48 & 85.7 & 8 & 14.3 \\
\hline DBD & 0 & 55 & 98.2 & 1 & 1.8 & 0 & 55 & 98.2 & 1 & 1.8 \\
\hline Sariawan & 0 & 55 & 98.2 & 1 & 1.8 & 0 & 55 & 98.2 & 1 & 1.8 \\
\hline Penyakit kulit & 0 & 52 & 92.9 & 4 & 7.1 & 0 & 52 & 92.9 & 4 & 7.2 \\
\hline Hepatitis B & 0 & 54 & 96.4 & 2 & 3.6 & 0 & 54 & 96.4 & 2 & 3.6 \\
\hline Demam & 0 & 42 & 75.0 & 14 & 25.0 & 0 & 42 & 75.0 & 14 & 25.0 \\
\hline Gabungan penyakit & 5 & 33 & 58.9 & 23 & 41.1 & 1 & 32 & 57.1 & 24 & 42.9 \\
\hline
\end{tabular}


diharapkan cukup menambah kandungan vitamin A dalam ASI sampai bayi berusia 6 bulan. Pada penelitian ini, jumlah kapsul vitamin A yang diberikan berjumlah 1 atau 2 kapsul. Kurang dari separuh vitamin A diberikan sebanyak 2 kapsul kepada ibu subjek (42.9\%). Pemberian suplemen vitamin A dilakukan oleh Bidan Desa dan Kader Posyandu. Sebagian besar pemberian suplemen vitamin A dilakukan oleh bidan (89.3\%). Kapsul vitamin A tersebut diperoleh dari Dinas Kesehatan Kabupaten Bogor.

Sebagian besar ibu subjek mengonsumsi vitamin A yang diberikan. Pemberian kapsul pertama dilakukan 1-6 jam setelah melahirkan, sementara kapsul kedua diberikan saat ibu nifas akan pulang dari rumah bidan atau puskesmas tempat melahirkan. Alasan ibu subjek mengonsumsi vitamin A tersebut adalah karena disuruh bidan atau kader (94.6\%) dan hanya sebagian kecil yang mengetahui manfaatnya (5.4\%). Pada saat pemberian hanya $12.5 \%$ dari bidan atau kader yang menjelaskan manfaat atau waktu minum suplemen vitamin A. Lebih dari separuh ibu subjek mengaku merasakan manfaat dari konsumsi suplemen vitamin A tersebut (55.4\%). Manfaat yang dirasakan seperti kesehatan ibu cepat pulih setelah melahirkan, namun manfaat secara langsung untuk bayi belum dirasakan oleh ibu. Keseluruhan ibu subjek tidak pernah mengonsumsi suplemen vitamin $A$ dari luar program (100\%).

\section{Hubungan Riwayat Pemberian ASI dengan Morbidi-} tas

Riwayat pemberian ASI meliputi Inisiasi Menyusui Dini (IMD), kolostrum, ASI eksklusif, prelakteal dan makanan atau minuman tambahan selain ASI. Menurut Latham (2010), menyusui merupakan cara yang penting untuk mencegah defisiensi vitamin A pada bayi. Bayi yang menyusui cenderung akan lebih tercukupi kebutuhan vitamin A nya. Lebih dari separuh ibu subjek tidak melakukan IMD (51.8\%) dan sebanyak $48.2 \%$ ibu subjek melakukan IMD. Menurut Edmond et al. (2006), risiko morbiditas dan mortalitas neonatal dan bayi bisa dicegah dengan IMD dan menyusui eksklusif selama 6 bulan. Berdasarkan hasil penelitian Fikawati dan Syafiq (2003), ibu yang tidak melakukan immediate breastfeeding (menyusui segera $\leq 30$ menit setelah melahirkan) berisiko memberikan makanan atau minuman pralakteal 1.8 kali sampai 5.3 kali lebih besar dibandingkan ibu yang immediate breastfeeding. Selain itu ditemukan juga bahwa ibu yang melakukan immediate breastfeeding 2 sampai 8 kali lebih besar kemungkinannya untuk memberikan ASI secara eksklusif sampai 4 bulan dibandingkan dengan ibu yang tidak immediate breastfeeding.

Sebagian besar ibu memberikan ASI pertama pada waktu lebih dari 30 menit setelah melahirkan (87.5\%). Hasil uji Chi-Square menunjukkan bahwa tidak ada hubungan antara IMD dengan morbiditas (kejadian sakit, lama dan frekuensi sakit dari setiap jenis penyakit maupun gabungan semua jenis penyakit) ( $p>0.05)$.

Sebagian besar ibu subjek memberikan kolostrum kepada bayinya (94.6\%) dan hanya sebagian kecil ibu yang tidak memberikan kolostrum karena ibu menganggap kolostrum merupakan ASI yang kotor dan basi (5.4\%). Hasil uji Chi-Square menunjukkan bahwa tidak ada hubungan antara pemberian kolostrum dengan morbiditas subjek ( $p>0.05)$.

Data hasil penelitian menunjukkan bahwa hanya sebagian kecil subjek yang diberikan ASI eksklusif (16.1\%) dan sebesar $83.9 \%$ subjek tidak diberikan ASI eksklusif. Menurut Sundaram et al. (2013), pendidikan ibu, perawatan kehamilan dan dukungan selama kehamilan dan persalinan dapat mempromosikan pemberian ASI eksklusif. Selain itu menurut Aidam et al. (2005), peningkatan persentase menyusui eksklusif berkaitan dengan kegiatan konseling tentang laktasi. Rata-rata bayi menyusui selama $26.6 \pm 17.7$ menit dan rata-rata frekuensi menyusui dalam sehari sebanyak $12.3 \pm 1.4$ kali. Persentase subjek yang diberi ASI eksklusif sebagian besar termasuk dalam rentang umur $0-2$ bulan $(77.8 \%)$ dan sebesar $22.2 \%$ dalam rentang umur 3-6 bulan. Hasil uji Chi-Square menunjukkan bahwa tidak ada hubungan antara pemberian ASI eksklusif dengan morbiditas ( $p>0.05)$.

ASI eksklusif dapat memenuhi kecukupan gizi bayi sampai umur 6 bulan (EFSA 2009). Hampir separuh subjek diberi makanan atau minuman prelakteal sebelum mendapatkan ASI (44.6\%). Hasil uji Chi-Square menunjukkan bahwa tidak ada hubungan antara pemberian makanan atau minuman prelakteal dengan morbiditas $(p>0.05)$.

Sebagian besar subjek diberikan makanan atau minuman tambahan selain ASI setelah ASI keluar (76.8\%). Hasil uji Chi-Square menunjukkan bahwa tidak ada hubungan antara pemberian makanan atau minuman tambahan selain ASI dengan lama dan frekuensi sakit dari masing-masing jenis penyakit serta kejadian sakit (pernah tidaknya sakit) dengan nilai $p>0.05$. Selain itu, dilakukan pula uji Chi-Square dari masing-masing variabel terhadap lama dan frekuensi sakit dari gabungan semua jenis penyakit. Hasil uji Chi-Square menunjukkan bahwa terdapat hubungan antara pemberian makanan atau minuman tambahan selain ASI terhadap lama sakit $(\mathrm{p}<0.05)$, namun tidak terdapat hubungan antara pemberian makanan atau minuman tambahan selain ASI dengan frekuensi sakit $(p>0.05)$.

\section{Hubungan Jumlah Konsumsi Suplemen Vitamin A dan Praktek Imunisasi dengan Morbiditas}

Hasil uji Chi-Square menunjukkan bahwa terdapat hubungan antara jumlah konsumsi suplemen vitamin A dengan kejadian sakit (pernah tidaknya sakit) dengan nilai $p<0.05$ namun tidak terdapat 
hubungan dengan frekuensi dan lama sakit dari masing-masing jenis penyakit $(p>0.05)$. Selain itu, dilakukan pula uji Chi-Square dari masing-masing variabel terhadap lama dan frekuensi sakit dari gabungan semua jenis penyakit. Hasil uji Chi-Square menunjukkan bahwa tidak terdapat hubungan antara jumlah konsumsi suplemen vitamin A dengan lama dan frekuensi sakit dari gabungan frekuensi dan lama sakit semua jenis penyakit $(p>0.05)$.

Imunisasi lengkap pada bayi 0-6 bulan meliputi umur 0 bulan (HBO), 1 bulan (BCG, Polio 1), 2 bulan (Kombo 1, Polio 2), 3 bulan (Kombo 2, Polio 3), 4 bulan (Kombo 3, Polio 4). Sebagian besar subjek diimunisasi (92.9\%) namun hanya $26.9 \%$ diimunisasi lengkap berdasarkan umur masing-masing subjek. Hal tersebut dikarenakan beberapa alasan antara lain bayi sakit saat akan diimunisasi, ibu malas ke posyandu, ibu sibuk atau ibu sering lupa dengan jadwal posyandu.

Hasil uji Chi-Square menunjukkan bahwa ada hubungan antara praktek pemberian imunisasi dengan lama dan frekuensi penyakit hepatitis $B$ $(p<0.05)$. Namun tidak terdapat hubungan dengan kejadian sakit, lama dan frekuensi penyakit ISPA, demam, diare, demam berdarah, sariawan, dan penyakit kulit $(p>0.05)$. Selain itu, tidak terdapat pula hubungan antara kelengkapan imunisasi dengan kejadian sakit, lama dan frekuensi ISPA, demam, diare, demam berdarah, sariawan, hepatitis $B$, dan penyakit kulit $(p>0.05)$. Hasil uji Chi-Square menunjukkan bahwa terdapat hubungan antara kelengkapan imunisasi dengan lama sakit $(p<0.05)$, namun tidak terdapat hubungan antara kelengkapan imunisasi dengan frekuensi sakit serta pemberian imunisasi dengan lama dan frekuensi sakit $(p>0.05)$. Menurut Sadono et al. (2005), bayi yang tidak mendapatkan imunisasi sesuai umur berisiko menderita ISPA.

\section{Faktor-Faktor yang Memengaruhi Morbiditas}

Uji regresi logistik menunjukkan bahwa jumlah konsumsi vitamin A berpengaruh terhadap kejadian sakit $(\mathrm{OR}=0.103 ; 95 \% \mathrm{Cl}: 0.015-0.715)$ artinya subjek yang ibunya mengonsumsi 2 kapsul vitamin A dapat terproteksi dari kejadian sakit 0.103 kali dibandingkan subjek yang ibunya mengonsumsi 1 kapsul vitamin A. Menurut Depkes (2009), pemberian satu kapsul vitamin A merah cukup untuk meningkatkan kandungan vitamin A dalam ASI selama 60 hari dan pemberian 2 kapsul vitamin A merah diharapkan cukup menambah kandungan vitamin $A$ dalam ASI sampai bayi berusia 6 bulan.

Hasil uji regresi logistik juga menunjukkan bahwa kelengkapan imunisasi berpengaruh terhadap morbiditas (lama sakit subjek) (OR=0.110; 95\% Cl:0.013-0.940), artinya subjek yang diberikan imunisasi lengkap dapat terproteksi dari morbiditas 0.110 kali dibandingkan yang tidak diberikan imunisasi lengkap. Hasil penelitian Cicih (2011) menun- jukkan bahwa anak yang berstatus imunisasi tidak lengkap lebih rendah status kesehatannya dibandingkan yang status imunisasinya lengkap.

Kelengkapan imunisasi itu sendiri juga dipengaruhi oleh beberapa faktor. Penelitian Ningrum dan Sulastri (2008) menunjukkan bahwa pengetahuan dan motivasi ibu berpengaruh positif terhadap kelengkapan imunisasi, artinya semakin baik pengetahuan dan motivasi ibu akan berpengaruh meningkatkan kelengkapan imunisasi pada bayi. Menurut Pujiyanti (2008), kelengkapan imunisasi dan pemberian vitamin A berpengaruh terhadap status gizi. Hasil penelitian Hidayat dan Fuada (2011) menunjukkan bahwa status gizi berhubungan dengan morbiditas.

\section{KESIMPULAN}

Terdapat hubungan antara pemberian imunisasi dengan frekuensi dan lama sakit hepatitis $B$, jumlah konsumsi vitamin A dengan kejadian sakit (pernah/tidaknya sakit), kelengkapan imunisasi dan pemberian makanan atau minuman tambahan selain ASI dengan lama sakit semua jenis penyakit $(p<0.05)$. Kelengkapan imunisasi berpengaruh terhadap lama sakit subjek dimana subjek yang diberikan imunisasi lengkap dapat terproteksi dari morbiditas 0.110 kali dibandingkan yang tidak diberi imunisasi lengkap. Jumlah konsumsi vitamin A berpengaruh terhadap kejadian sakit dimana ibu subjek yang mengonsumsi 2 kapsul vitamin A dapat terproteksi dari kejadian sakit 0.103 kali dibandingkan subjek yang ibunya mengonsumsi 1 kapsul vitamin A.

Penelitian selanjutnya disarankan untuk menggunakan desain case control sehingga pengaruh suplementasi vitamin A antara kelompok kontrol dan kelompok perlakuan diharapkan dapat terlihat jelas.

Vitamin A di dalam tubuh sebaiknya diperoleh dari pangan yang menjadi sumber vitamin A. Suplementasi vitamin A perlu diberikan jika tidak mampu memenuhi kebutuhan vitamin A dari makanan namun sasarannya harus jelas dan tepat. Perlunya sosialisasi mengenai program suplementasi vitamin A pada ibu nifas untuk meningkatkan pengetahuan mengenai manfaat dan jumlah kapsul yang seharusnya diberikan.

\section{DAFTAR PUSTAKA}

Aidam BA, Escamilla RP, \& Lartey A. 2005. Lactating counseling increases exclusive breastfeeding rate in Ghana. J Nutr, 135, 1691-1695.

Almatsier S. 2004. Prinsip Dasar Ilmu Gizi. Gramedia Pustaka Utama, Jakarta.

Ayah RA, Mwaniki DL, Magnussen P, Tedstone AE, Marshall T, Alusala D, Luoba A, Kaestel P, Michaelsen KF, \& Friis H. 2007. The effects of 
maternal and infant vitamin A supplementation on vitamin A status: a randomized trial in Kenya. British Journal of Nutrition, 98, 422430.

Basu S, Sengupta B, \& Paladhi PKR. 2003. Single megadose vitamin A supplementation of Indian mothers and morbidity in breastfed young infants. Posgrad Med J, 79, 397-402.

Cicih LHM. 2011. Pengaruh perilaku ibu terhadap status kesehatan anak baduta di Provinsi Jawa Tengah. Sari Pediatri, 13(1), 41-8.

[Depkes RI] Departemen Kesehatan Republik Indonesia. 2009. Panduan Suplementasi Vitamin A. Depkes RI, Jakarta.

[Dinkes] Dinas Kesehatan. 2012. Data Kesehatan Dasar. Dinkes, Bogor.

Edmond KM, Zandoh C, Quigley MA, Amenga S, Owusu S, \& Kirkwood BR. 2006. Delayed breastfeeding initiation increases risk of neonatal mortality. Pediatrics, 117, e380. DOI: 10.1542/peds. 2005-1496.

[EFSA] European Food Safety Authority. 2009. Scientific opinion on the appropriate age for introduction of complementary feeding of infants. EFSA journal, 7(12), 1423.

Fikawati S \& Safiq A. 2003. Hubungan antara menyusui segera (immediate breasfeeding) dan pemberian ASI eksklusif sampai dengan empat bulan. J Kedokter Trisakt, 22, 47-55.

Gogia S \& Sachdev HS. 2010. Maternal postpartum vitamin A supplementation for the prevention of mortality and morbidity in infancy: a systemic review of randomized controlled trials. International Journal Of Epidemiology, 39, 1217-1226.

Hidayat TS \& Fuada. 2011. Hubungan sanitasi lingkungan, morbiditas dan status gizi balita di Indonesia. Penel Gizi Makan, 34(2), 104-113.

Latham M. 2010. The great vitamin A fiasco. World nutrition, 1(1), 12-45.

Malaba LC, Iliff PJ, Nathoo KJ, Marinda E, Moulton LH, Zijenah LS, Zvandasara P, Ward BJ, Zvitambo, \& Humprey JH. 2005. Effect of postpartum maternal or neonatal vitamin A supplementation on infant mortality among infants born to HIV-negative mothers in Zimbabwe. Am J Clin Nutr, 81, 454-60.

Martins TM, Ferraz IS, Daneluzzi JC, Martinelli CE Jr, Del Ciampo LA, Ricco RG, Jordao AA Jr, Patta MC, \& Vannucchi H. 2010. Impact of maternal vitamin A supplementation on the motherinfant pair in Brazil. Eur J Clin Nut, 64(11), 1302-7. doi: 10.1038/ejcn.2010.165.
Menegozzo JM-Oliveira, Bergamaschi DP, Middleton P, \& East CE. 2010. Vitamin A supplementation for pospartum woman. The cochrane collaboration, DOI: 10.1002/14651858.CD005944. pub2.

Newton S, Cousens S, Agyei SO, Filteau S, Stanley C, Linsell L, \& Kirkwood B. 2005. Vitamin A supplementation does not affect infant's immune responses to polio and tetanus vaccines. J Nutr, 135, 2669-2673.

Ningrum EP \& Sulastri. 2008. Faktor-faktor yang mempengaruhi kelengkapan imunisasi dasar pada bayi di Puskesmas Banyudono Kabupaten Boyolali. Berita ilmu keperawatan ISSN, 1(1), 7-12.

Pujiyanti S. 2008. Pengaruh pemberian ASI, konsumsi zat gizi, dan kelengkapan KMS terhadap status gizi bayi. Jurnal Gizi dan Pangan, 3(1), 7-11.

Ramakrishnan U, Latham MC, Abel R, \& Frongillo EA Jr. 1995. Vitamin A supplementation and morbidity among preschool children in South India. Am J Clin Nutr, 61(6), 1295-303.

Rice AL. 2007. Postpartum vitamin A supplementation: evaluating the evidance for action. USAID, 1-12.

Ross JS \& Harvey PWJ. 2003. Contribution of breastfeeding to vitamin A nutrition of infants: a simulation model. Bulletin of the World Health Organization, 81, 80-86.

Sadono W, Adi MS, \& Zain MS. 2005. Bayi berat lahir rendah sebagai salah satu faktor risiko infeksi saluran pernafasan akut pada bayi (studi kasus di Kabupaten Blora). Jurnal Epidemiologi Universitas Diponegoro.[Internet]. [diunduh tanggal 13 September 2013]. Tersedia pada: http://eprints.undip.ac.id/5249/1/ Sadono_ Wiwoho.pdf.

Sundaram ME, Labrique AB, Mehra S, Ali H, Shamim AA, Klemm RDW, West KP, \& Christian P. 2013. Early neonatal feeding is common and associated with subsequent breastfeeding behavior in rural Bangladesh. J Nutr, 143, 1161-1167.

Untoro J, Karyadi E, Wibowo L, Erhardt MW, \& Gross R. 2005. Multiple micronutrient supplements improve micronutrient status and anemia but not growth and morbidity of Indonesian infants. J Nutr, 135, 639S-645S.

[WHO] World Health Organization. 2011. Guideline vitamin A supplementation in postpartum women. World Health Organization, Geneva. 